\title{
The Impact of the Interaction of Financial and Industrial Structure on Economic Growth - Evidence from China
}

\author{
Yiqian $\operatorname{Tan}^{1}$, Fan Jiang ${ }^{2, *}$ \\ ${ }^{1}$ SILC Business School, Shanghai University, Jiading District, Shanghai, China \\ ${ }^{2}$ SILC Business School, Shanghai University, Jiading District, Shanghai, China
}

\begin{abstract}
In recent years, China's economic growth speed has been slowing down, leading to the problems of overcapacity and unbalanced regional economic development, and the mismatch between industrial and financial structure is becoming intense. This paper, starting with the relationship among economic growth, industrial structure and financial structure, summarizes the research by the former scholars. On this basis, by using data of 31 provincial panel data in China from 2007 to 2016, the article aims to find out the relationship between the industrial structure and economic growth, the relationship between the financial structure and economic growth and the relationship between the interaction of financial and industrial structure and economic growth. Finally, the conclusions of this paper are obtained that the interaction between the financial structure and the industrial structure can promote the economic growth significantly. However, the matching effect of the financial structure and industrial structure in China has not been completely formed, and the industrial upgrading should be guided to be structurally reformed through the policy.
\end{abstract}

\section{Introduction}

China's economy is in the transition period of digesting the early incentive policies and structural adjustment and optimization. The main reasons are the slow upgrading of industrial structure and the financing mode cannot meet the needs of industrial structure adjustment. At the same time, the gap of regional economic development is gradually widening, and the industrial structure and financial structure do not match. In terms of industrial structure, the development is unreasonable and the transformation is difficult. Many enterprises also lack the ability of independent innovation, which leads to the low added value of products and backward profit model. In terms of financial structure, the scale of financing is increasing, and the types of financial instruments are also increasing. However, there are still some problems in the financing of enterprises, mainly the financing difficulties of technology-based private enterprises. How to ensure that the local industrial structure and financial structure match each other and correctly guide the rectification and transformation of enterprises is of great strategic significance for China's economic transformation in the future.

Previous studies have analyzed the relationship between financial structure, industrial structure and economic growth. Gong ${ }^{3}(2014)$ the financial structure dominated by the bank is suitable for China's economic development stage. The factor endowment structure with abundant labor and relatively scarce capital determines the current situation of the industrial structure of laborintensive mature manufacturing industry. $\mathrm{Ye}^{4}(2018)$ analyzed cross-border panel data and found that the suitability of financial structure has a significant positive effect on economic growth, the suitability of the relative proportion of securities market and bank is more significant in developed economies, the suitability of internal structure of banking industry is more important in developing countries, and the suitability of financial structure and industrial structure of each country has a more significant impact on economic growth It's important. Zheng ${ }^{5}(2019)$ tested the panel data of prefecture level cities, and found that local financial development promoted the upgrading of local industrial structure, and also promoted the neighboring cities.

A great deal of theoretical and empirical research pertains on the mechanism of financial structure and industrial structure on economic growth. But previous research only studies some factors of economic growth, but few investigates the interaction between financial structure and industrial structure, nor the impact on economic growth. In addition, if the research on the relationship between financial or industrial structure and economic growth will lead to incomplete research results, there is still an impact mechanism on economic growth in the matching effect of financial structure and industrial structure. Therefore, the relationship between industrial structure, financial structure and economic

*Corresponding author: 18055014479@163.com 
growth should be integrated. The empirical analysis of the current research mainly focuses on vector autoregression model, time series model, Granger causality analysis and unit root cointegration test, and few scholars use panel data to do empirical analysis. Therefore, it is necessary to build a complete evaluation system of the impact of industrial structure and financial structure interaction on economic growth, and accurately and comprehensively select various evaluation indicators.

In addition, previous research has analyzed the correlation between the verification indexes vertically, which makes the explanatory variables and economic growth indicators form a relatively simple linear relationship. The models used in the study are also basically linear models, such as time series model and directed autoregression. Because the internal mechanism between economic growth and financial development and industrial structure in various regions is relatively complex, a lot of research verifies the long-term correlation between variables. However, the study of the industrial structure determined by the factor endowment of each region, the financial structure guided by the demand of industrial structure and the local differences of economic growth under the interaction of the two factors have not been analyzed in detail. Therefore, this paper uses the fixed effect model to analyze the influence of the interaction between financial structure and industrial structure on economic growth, and constructs a complete and systematic research framework to sort out the relationship between industrial structure, financial development and economic growth, which has important theoretical innovation value.

\section{The Data}

This paper selects the data of industrial structure, financial structure, economic growth and other selected control variables of 31 provinces in China from 2007 to 2016. In addition to the financial structure, the rest of the data are from China's national statistical yearbook. The measurement of financial structure index needs the balance of deposit and loan of regional banks, which comes from wind database. The data itself is incomplete and lost, so the data is processed: the data of education funds in some areas in 2012 is missing, combined with the data of 2011, calculated by the average annual growth rate. This paper selects the financial correlation rate as the index to measure the financial structure, and its calculation method needs the ratio of the total value of regional financial assets to the GDP of regional income method. However, the statistics of the total value of regional financial assets in China is not complete, so this paper uses the total balance of deposits and loans of regional financial institutions (banks) instead. The variables that can reflect the characteristics of financial structure, industrial structure, regional economic environment, regional consumption level, education investment level, regional import and export trade level, regional previous investment and fixed asset investment are selected for descriptive analysis. All variables are shown in Table I.

\section{TABLE I. VARIABLE DESCRIPTIVE Statistics}

\begin{tabular}{|c|c|l|l|l|c|}
\hline Variable & $\mathbf{N}$ & Mean & Std Dev & Min & Max \\
\hline PGDPGR & 310 & 12.90 & 7.558 & -22.28 & 37.01 \\
\hline FIR & 310 & 2.874 & 1.138 & 1.288 & 8.131 \\
\hline STA & 310 & 1.150 & 0.345 & 0.240 & 2.012 \\
\hline FIR*STA & 310 & 1.375 & 0.981 & 0.279 & 6.608 \\
\hline LGPGDP & 310 & 4.539 & 0.237 & 3.896 & 5.073 \\
\hline CPI & 310 & 103.1 & 2.043 & 97.70 & 110.1 \\
\hline EDU & 310 & 6.322 & 0.817 & 3.739 & 8.119 \\
\hline TRADE & 310 & 5.706 & 1.717 & 1.060 & 9.458 \\
\hline INVEST & 310 & 5.985 & 1.528 & 1.627 & 9.082 \\
\hline ESTATE & 310 & 8.955 & 1.008 & 5.600 & 10.88 \\
\hline
\end{tabular}

Note: in order to reduce the instability of data and overcome heteroskedasticity to a certain extent, some absolute variables in the model are logarithmically treated.

The overall economic growth rate of each region in China is relatively good. From the average value, the overall average is $12.89 \%$, indicating that the overall economic development of our country is in good condition. However, the standard deviation is 7.558, which indicates that the economic growth rate is not concentrated in various regions, and it is in a polarization. The distance between the maximum and minimum values is huge, with a difference of more than 50 percentage points, indicating that there is a great difference between regions. From the data of financial correlation rate, the average value is 2.874 , which represents that the bank led indirect financing method occupies a large proportion in China, and the financial correlation rate increases year by year.

From the perspective of industrial structure index, the index used in this paper is the ratio of the added value of the second industry to the added value of the third industry. The average ratio of industrial structure is 1.15 , which shows that the secondary industry is still the largest in China. However, from the change trend of the proportion of industrial structure, China is gradually moving towards the third industry led economic growth model. From the perspective of maximum minimum distance and standard deviation, the current industrial structure of each region is diverse. The maximum value of industrial structure proportion shows that the added value of the secondary industry accounts for $2 / 3$ of the added value of the whole province, and the minimum value shows that the added value of the tertiary industry accounts for $4 / 5$ of the added value of the whole province.

\section{Empirical Analysis}

Previous theories on the influence mechanism of financial structure and industrial structure on economic growth are often too one-sided and rigid, and the industrial structure and financial structure of various regions are usually constantly changing, and due to the limitation of resources and other factors, the economic environment of various regions is very different, so these theories usually cannot be applied to all regions. Therefore, this paper combines the current economic 
environment, through empirical research to explore the applicable industrial structure of each region, and whether the matching of financial structure and industrial structure will have a significant impact on regional economic growth. The sample selection of this paper is based on the relevant financial variables (such as financial correlation rate, the proportion of added value of the secondary industry and economic growth indicators) and relevant control variables (such as economic scale indicators and regional consumption level indicators) of 31 provinces and cities from 2007 to 2016, and empirically analyze the internal relationship between financial structure, industrial structure and economic growth.

\subsection{Hypothesis}

Hypothesis 1: the optimization of financial structure will have a positive impact on economic growth. The financial structure is measured by the financial correlation rate, which represents the ratio of the total balance of deposits and loans of regional financial institutions to the GDP. It is used to express the market share of indirect financing and the degree of deepening of the financial structure. Generally, in a region dominated by industry, the promotion of indirect financing will have a significant positive impact on economic growth.

Hypothesis 2: the proportion of industrial structure (the added value of the secondary industry is higher than that of the tertiary industry) will have a positive impact on economic growth on the whole, which proves that most regions of China are suitable for the indirect financing model represented by the bank led model. However, in the sub regional analysis, for some regions, the increase in the proportion of the secondary industry will have a negative impact on economic growth.

Hypothesis 3: the matching effect of financial structure and industrial structure has a significant positive impact on economic growth. Only when a region's industrial structure and financial structure match each other, the market can play the maximum benefit, and the financing efficiency will be maximized, thus making the rapid economic growth.

Details of all variables are summarized in Table II.

TABLE II. VARIABLE SUMMARY

\begin{tabular}{|c|c|c|}
\hline & Variable name & Variable definition \\
\hline Explained variable & $\begin{array}{l}\text { Regional per capita GDP growth } \\
\text { rate(PGDPGR) }\end{array}$ & $\begin{array}{l}\text { Indicates the speed of regional economic } \\
\text { growth }\end{array}$ \\
\hline \multirow[t]{3}{*}{ Explanatory variables } & $\begin{array}{l}\text { Financial Interrelations } \\
\text { Ratio(FIR) }\end{array}$ & $\begin{array}{l}\text { Indicates the tendency of regional financial } \\
\text { structure }\end{array}$ \\
\hline & Industrial structure ratio(STA) & $\begin{array}{c}\text { Indicates the introversion of regional } \\
\text { industrial structure }\end{array}$ \\
\hline & $\begin{array}{c}\text { Cross multiply item of financial } \\
\text { structure and industrial } \\
\text { structure(FIR*STA) }\end{array}$ & $\begin{array}{l}\text { Indicates the matching effect of financial } \\
\text { structure and industrial structure }\end{array}$ \\
\hline \multirow[t]{6}{*}{ Control variables } & $\begin{array}{l}\text { Logarithm of GDP per capita } \\
\text { (LGPGDP) }\end{array}$ & $\begin{array}{c}\text { Indicates the scale of regional economic } \\
\text { development }\end{array}$ \\
\hline & Consumer price index $(\mathrm{CPI})$ & Indicates the regional inflation rate \\
\hline & Education expenditure (EDU) & $\begin{array}{c}\text { Indicates the importance of education in the } \\
\text { region }\end{array}$ \\
\hline & Total regional trade (TRADE) & $\begin{array}{l}\text { Indicates the region's dependence on import } \\
\text { and export trade }\end{array}$ \\
\hline & $\begin{array}{l}\text { Foreign direct investment } \\
\text { (INVEST) }\end{array}$ & $\begin{array}{l}\text { Indicates the attraction of the region to } \\
\text { foreign investment }\end{array}$ \\
\hline & $\begin{array}{l}\text { Regional total investment in } \\
\text { fixed assets of the whole society } \\
\text { (ESTATE) }\end{array}$ & $\begin{array}{l}\text { Indicates the degree of regional capital } \\
\text { accumulation }\end{array}$ \\
\hline
\end{tabular}

\subsection{Empirical Results}

\subsubsection{Correlation test}

Pearson correlation coefficient, also known as product difference correlation coefficient, is the most commonly used correlation coefficient. The value of -1 to 1 , the greater the absolute value, the stronger the correlation is; the symbol is positive correlation between positive description variables and negative symbol, indicating that it is negative correlation. This paper uses Pearson correlation test to investigate the correlation among variables. The results are shown in Table 4. Except for positive correlation with STA and CPI, PGDPGR is negatively correlated with other variables. In addition, we take correlation coefficient higher than 0.8 as the basis of strong correlation. Except for the correlation between TRADE and INVEST, other variables are less than 0.8 , which indicates that there is no obvious multicollinearity in the model ${ }^{\mathrm{a}}$.

\footnotetext{
${ }^{a}$ Due to space limit, all appendices can be found on https://www.jianguoyun.com/p/DUX0QpcQhJWfCRiXquID
} 


\subsubsection{Basic results}

Regression analysis of regional per capita GDP growth rate:

$P G D P G R=\alpha+\beta_{1} F I R_{\mathrm{it}}+\beta_{2} S T A_{\mathrm{it}}+\beta_{3} F_{I R S T A_{\mathrm{it}}}+\delta X_{\mathrm{it}}+\lambda_{\mathrm{i}}+\mu_{\mathrm{i}}+\varepsilon_{\mathrm{it}}$

in which $\beta_{1}$ reflects the correlation between financial structure and economic growth. If its sign is positive, it indicates that the region is suitable for the development of indirect financing led financial structure. $\beta_{2}$ reflects the correlation between industrial structure and economic growth. Meanwhile, the sign of $\beta_{3}$ is expected to be positive.

TABLE III. REGRESSION BASED ON FIXED EFFECT

\begin{tabular}{|c|c|c|c|c|c|}
\hline & (1) & (2) & (3) & (4) & (5) \\
\hline & PGDPGR & PGDPGR & PGDPGR & PGDPGR & PGDPGR \\
\hline \multirow[t]{2}{*}{ FIR } & -0.0770 & -0.1722 & 0.3840 & $\begin{array}{c}0.3614 \\
*\end{array}$ & $\begin{array}{c}0.5045 \\
* *\end{array}$ \\
\hline & $(-0.547)$ & $(-0.614)$ & $(1.110)$ & (1.911) & $(2.099)$ \\
\hline \multirow[t]{2}{*}{ STA } & $\begin{array}{c}22.4241 \\
* * *\end{array}$ & $\begin{array}{c}22.3490 \\
* * *\end{array}$ & $\begin{array}{c}15.7151 \\
* * *\end{array}$ & $\begin{array}{c}8.6076 \\
* * *\end{array}$ & $\begin{array}{c}9.4327 \\
* * *\end{array}$ \\
\hline & $(9.076)$ & $(9.209)$ & $(5.209)$ & (3.224) & $(3.861)$ \\
\hline \multirow[t]{2}{*}{ FIR*STA } & & 0.1766 & -0.4417 & -0.0264 & -0.1684 \\
\hline & & $(0.357)$ & $(-0.844)$ & $(-0.062)$ & $(-0.335)$ \\
\hline \multirow[t]{2}{*}{ TRADE } & & & -0.9486 & 0.0363 & 0.9821 \\
\hline & & & $(-0.622)$ & $(0.036)$ & $(0.861)$ \\
\hline \multirow[t]{2}{*}{ INVEST } & & & $\begin{array}{c}-6.8077 \\
* * *\end{array}$ & -0.6509 & -0.1296 \\
\hline & & & $(-4.195)$ & $(-0.596)$ & $(-0.124)$ \\
\hline \multirow[t]{2}{*}{ LGPGDP } & & & & $-6.2959 * * *$ & $-19.8246^{* *}$ \\
\hline & & & & $(-2.847)$ & $(-2.498)$ \\
\hline \multirow[t]{2}{*}{ CPI } & & & & $1.8608^{* * *}$ & $2.0870 * * *$ \\
\hline & & & & $(15.532)$ & $(12.186)$ \\
\hline \multirow[t]{2}{*}{ ESTATE } & & & & & $10.3690^{*}$ \\
\hline & & & & & $(1.760)$ \\
\hline \multirow[t]{2}{*}{ EDU } & & & & & -2.5007 \\
\hline & & & & & $(-0.709)$ \\
\hline \multirow[t]{2}{*}{ _cons } & $\begin{array}{c}-12.7838 \\
* * *\end{array}$ & $\begin{array}{c}-12.7996 \\
* * *\end{array}$ & $\begin{array}{c}41.0209 \\
* * *\end{array}$ & $\begin{array}{c}-1.2 \mathrm{e}+02 \\
* * *\end{array}$ & $\begin{array}{c}-88.2171 \\
* * *\end{array}$ \\
\hline & $(-4.390)$ & $(-4.371)$ & $(4.198)$ & $(-5.700)$ & $(-2.894)$ \\
\hline $\mathbf{N}$ & 310 & 310 & 310 & 310 & 310 \\
\hline
\end{tabular}

Note: variables in brackets are $\mathrm{t}$ values, $* *, *$, and $*$ indicate significant at $1 \%, 5 \%$, and $10 \%$ levels respectively.

Table III shows the regression results of the whole sample. Model (1) is the regression result of the influence of explanatory variables FIR and STA on PGDPGR. Model (2) introduces the interaction term FIR*STA between FIR and STA on the basis of model (1) to verify the regulatory role of STA between financial development and economic growth. Model (3) model (5) gradually introduces foreign trade variables, internal economic development variables and previous investment variables and educational variables. According to the regression results, the significance of FIR coefficients in models (1)-(5) is not robust, models (4) and (5) are only at the significance levels of $10 \%$ and $5 \%$, and other models are not significant. The estimated values of STA coefficients are significant at the $1 \%$ significance level, and are positively correlated, indicating that the improvement of STA will promote economic growth. The interaction coefficients were not significant. Therefore, the significance of the explanatory variable FIR and interaction term is low. We think that there may be some problems in the model, such as cross-sectional correlation, endogeneity and heteroskedasticity. Therefore, we will test the crosssectional correlation, endogeneity and heteroskedasticity of the model.

For robustness check, this paper uses the generalized least squares regression (GLS) to eliminate the influence of autocorrelation and heteroskedasticity on the model.

\subsubsection{Regression results of modified GLS model}

Under GLS regression, the regression results were significantly better than fixed effect regression, and the coefficients of FIR and interaction terms were significantly improved. The regression results are shown in table IV.

TABLE IV. EMPIRICAL RESUlts BASEd ON GLS REgRESSION

\begin{tabular}{|c|c|c|c|c|c|}
\hline & (1) & (2) & (3) & (4) & (5) \\
\hline & PGDPGR & PGDPGR & PGDPGR & PGDPGR & PGDPGR \\
\hline \multirow{2}{*}{ FIR } & -0.5043 & 0.2316 & 0.6554 & 0.4677 & 0.2803 \\
& $* *$ & & $* * *$ & $* * *$ & $* * *$ \\
\hline & $(-2.062)$ & $(1.332)$ & $(5.620)$ & $(4.074)$ & $(1.212)$ \\
\hline
\end{tabular}




\begin{tabular}{|c|c|c|c|c|c|}
\hline STA & $\begin{array}{c}5.8634 \\
* * *\end{array}$ & $\begin{array}{c}8.2634 \\
* * *\end{array}$ & $\begin{array}{c}8.6184 \\
* * *\end{array}$ & $\begin{array}{c}4.8002 \\
* * *\end{array}$ & $\begin{array}{c}4.8164 \\
* * *\end{array}$ \\
\hline & $(4.327)$ & $(7.600)$ & $(8.445)$ & $(4.003)$ & $(2.660)$ \\
\hline FIR*STA & & $\begin{array}{c}-1.2364 \\
* * *\end{array}$ & $\begin{array}{c}-1.6181 \\
* * *\end{array}$ & -0.1448 & $\begin{array}{c}-0.7321 \\
* *\end{array}$ \\
\hline & & $(-2.796)$ & $(-3.570)$ & $(-0.328)$ & $(-1.425)$ \\
\hline Controls & YES & YES & YES & YES & YES \\
\hline $\begin{array}{l}\text { Provincial \& Year } \\
\text { Fixed Effect }\end{array}$ & YES & YES & YES & YES & YES \\
\hline $\mathbf{N}$ & 310 & 310 & 310 & 310 & 310 \\
\hline Wald test & $\begin{array}{c}47.81 \\
(0.000)\end{array}$ & $\begin{array}{c}78.51 \\
(0.000)\end{array}$ & $\begin{array}{l}196.27 \\
(0.000)\end{array}$ & $\begin{array}{l}945.12 \\
(0.000)\end{array}$ & $\begin{array}{l}257.00 \\
(0.000)\end{array}$ \\
\hline $\begin{array}{c}\text { Heteroskedasticity } \\
\text { test }\end{array}$ & $\begin{array}{c}63.53 \\
(0.0003) \\
\end{array}$ & $\begin{array}{c}65.96 \\
(0.0002) \\
\end{array}$ & $\begin{array}{c}72.21 \\
(0.0000) \\
\end{array}$ & $\begin{array}{c}94.96 \\
(0.0000) \\
\end{array}$ & $\begin{array}{r}103.87 \\
(0.0000) \\
\end{array}$ \\
\hline Endogeneity test & $\begin{array}{l}51.118 \\
(0.0000)\end{array}$ & $\begin{array}{c}67.179 \\
(0.0000)\end{array}$ & $\begin{array}{c}82.914 \\
(0.0000)\end{array}$ & $\begin{array}{c}79.691 \\
(0.0000)\end{array}$ & $\begin{array}{r}77.572 \\
(0.0000) \\
\end{array}$ \\
\hline
\end{tabular}

Note: variables in brackets are $\mathrm{t}$ value, Wald, heteroskedasticity, and sequence correlation tests are $\mathrm{p}$ value, $* *, *$, and $*$ indicate significant at $1 \%, 5 \%$, and $10 \%$ levels, respectively.

Table IV shows the regression results between the explanatory variables and the interpreted variables:

a) From the regression results, we can see that under the control variables of trade environment, economic environment and investment environment (model 2-5), most of the model FIR are at the 1\% significance level, which is significantly positively correlated with PGDPGR, indicating that the higher the FIR level is, the more economic growth will be promoted. This supports the conclusion that banks are dominant. That is to say, most areas of our country are suitable for the financial structure dominated by indirect financing, which confirms the hypothesis of this paper. The main reason is that China's small and medium-sized industrial enterprises, as the representative, do not have the conditions for direct financing, so most of the financing channels are bank loans with asset mortgage. At the same time, from the perspective of social financing, indirect financing is welcomed by the Chinese people. The main reason is that the risk tolerance of the Chinese people is relatively weak. Through savings and bank fund investment and financing, we can have a stable income under the condition of ensuring low risk.

b) The proportion of industrial structure (the added value of the secondary industry is higher than that of the tertiary industry) is significant at $1 \%$ significance level in each model, and is positively correlated with PGDPGR. This shows that, from the perspective of the overall economic development stage, China is still in the development stage of heavy industry, and the internal restructuring and adjustment of the secondary industry is still the leading force driving economic growth.

c) The interaction between financial structure and industrial structure is significant except that the model (4) is not significant, and the symbol is negative. This shows that when the industrial structure and financial structure of a region cannot match each other, the role of financial structure and industrial structure on economic growth will be greatly weakened. This situation is shown that when China develops heavy industry enterprises with the second industry as the leading force, it cannot get the support of banks and other indirect financing channels in the financial level, or develop IT enterprises in the areas dominated by bank financing. Banks refuse to provide financing because the enterprises have no guarantee of fixed assets. The matching efficiency of funds has been weakened to some extent, thus hindering economic development.

\subsubsection{Robustness tests}

In order to ensure the validity of the estimation results, this paper will test the robustness of the above research conclusions. Furthermore, FIR2 (regional total stock trading volume / GDP) is used as an indicator to measure the level of financial development, instead of the previous results of regional total bank deposits and loans / GDP. At the same time, we still use GLS estimation method, and the estimation results are shown in Table $\mathrm{V}$ :

TABle V. RoBustness Tests(FIR2)

\begin{tabular}{|c|c|c|c|c|c|}
\hline & (1) & (2) & (3) & (4) & (5) \\
\hline & PGDPGR & PGDPGR & PGDPGR & PGDPGR & PGDPGR \\
\hline \multirow[t]{2}{*}{ FIR2 } & $\begin{array}{c}-1.9117 \\
* * *\end{array}$ & -0.9820 & $\begin{array}{c}1.3435 \\
* *\end{array}$ & $\begin{array}{c}1.3135 \\
* * *\end{array}$ & $\begin{array}{c}1.0929 \\
* *\end{array}$ \\
\hline & $(-2.803)$ & $(-0.573)$ & $(2.343)$ & $(2.944)$ & $(1.296)$ \\
\hline \multirow[t]{2}{*}{ STA } & $\begin{array}{c}6.0513 \\
* * *\end{array}$ & $\begin{array}{c}10.7900 \\
* * *\end{array}$ & $\begin{array}{c}15.1176 \\
* * *\end{array}$ & $\begin{array}{c}8.9811 \\
* * *\end{array}$ & $\begin{array}{c}7.5648 \\
* * *\end{array}$ \\
\hline & $(9.416)$ & $(2.684)$ & $(4.018)$ & $(6.678)$ & $(2.555)$ \\
\hline $\begin{array}{c}\text { FIR2 } * \text { ST } \\
\text { A }\end{array}$ & & $\begin{array}{c}-2.5646 \\
*\end{array}$ & $\begin{array}{c}-4.2988 \\
* * *\end{array}$ & $\begin{array}{c}-1.9093 \\
* * *\end{array}$ & $\begin{array}{c}-1.5886 \\
* *\end{array}$ \\
\hline
\end{tabular}




\begin{tabular}{|c|c|c|c|c|c|}
\hline & & $(-1.812)$ & $(-4.196)$ & $(-3.161)$ & $(-2.003)$ \\
\hline Controls & YES & YES & YES & YES & YES \\
\hline $\begin{array}{l}\text { Provincia } \\
\text { I \& Year } \\
\text { Fixed } \\
\text { Effect }\end{array}$ & YES & YES & YES & YES & YES \\
\hline $\mathbf{N}$ & & & & & \\
\hline Wald test & 113.91 & 48.07 & 53.85 & 1412.17 & 162.84 \\
\hline $\begin{array}{c}\text { Heterosk } \\
\text { edasticity } \\
\text { test }\end{array}$ & $(0.0000)$ & $(0.0000)$ & $(0.0000)$ & $(0.0000)$ & $(0.0000)$ \\
\hline $\begin{array}{c}\text { Endogene } \\
\text { ity test }\end{array}$ & $(0.0009)$ & $(0.00001)$ & $(0.0001)$ & $(0.0000)$ & $(0.0000)$ \\
\hline
\end{tabular}

Note: variables in brackets are $t$ value, Wald, heteroskedasticity, and sequence correlation tests are $\mathrm{p}$ value, $* *, *$, and $*$ indicate significant at $1 \%, 5 \%$, and $10 \%$ levels, respectively.

From table V, it can be seen that the results of GLS regression estimation are quite robust. The results ofFIR2,STA, and interaction term FIR2*STA are basically consistent with table IV. The results of this paper are effective.

\section{Conclusion and policy Suggestions}

Based on the panel data of 31 provinces in China from 2007 to 2016, this paper discusses the relationship between industrial structure, financial structure and economic growth. Finally, it concludes that the interaction between financial structure and industrial structure can significantly promote economic growth.However, most of China's areas are currently in the situation of mismatch between industrial structure and financial structure, and the industrial structure is in the transition stage. In order to help the region to accurately locate the industrial structure and make the financial structure match the industrial structure to promote the rapid economic growth of the region, the following suggestions are put forward:

\subsection{Industrial structure adjustment strategy}

Industrial transformation and upgrading. The empirical study found that the continued development of the secondary industry in China still has a promoting effect on economic growth, so at present, China still needs to continue to develop the secondary industry, but at the same time to implement the development principle of consumption reduction and transformation. For the traditional industrial industry, we should encourage Marketization, encourage enterprises to innovate independently, update technology, achieve high efficiency, combine information technology with industrialization, and introduce high-tech enterprises Technical personnel, improve product quality. The new industrialization road is the best choice for China's industrial transformation. The supply side reform is implemented by eliminating backward production capacity, rectifying and renewing the original backward technology enterprises, merging and restructuring. Only by taking steel as the main representative of the capital intensive industry, can it get new life and further development.

The characteristics of local industry development in different regions. According to the local conditions, the development strategy should be made. For example, the central and western regions of China are characterized by high energy consumption and high pollution. Through policy guidance and financial structure regulation, the region should gradually reduce the energy consumption of such industries, eliminate backward production capacity, and achieve high efficiency and environmental protection through technological innovation. Only in this way can the profit model of industrial sector be changed from low-cost model to high value-added model, and the economy can grow steadily for a long time.

The development of emerging industries. In addition to continuing to update and develop basic industries, it is equally important to develop new industries. We should introduce high-tech talents to inject fresh blood into China's industrial structure, such as the Internet industry. Starting from the developed areas, through the development of the Internet industry, in order to gradually drive the development of other regions. At the same time, all regions should pay attention to the existing technology intensive enterprises with good development momentum and potential, introduce relevant policies to encourage the development of enterprises, retain talents for enterprises, encourage enterprise transformation and innovation, and promote the coordinated and healthy development of the industry.

\subsection{Financial structure adjustment strategy}

Continue to promote the bank led financial model. This paper uses the financial correlation rate as the index of financial structure to reflect the size of the capital of the banking industry. The indirect financing mode dominated by banks in China can significantly promote economic growth. It can be combined with the adjustment and optimization program of China's industrial structure to launch more financial services and products to help enterprises innovate and develop. At the same time, banks should launch a variety of fund business and savings business to meet the needs of most people's preference for low-risk investment and financial management to ensure fixed income. 
Improve the matching degree of financial structure and industrial structure. Therefore, while adjusting the industrial structure, we should take into account the different degrees of development of the financial industry in different regions, combined with the elements and characteristics of local development, and put forward targeted and personalized financial development policies suitable for different regions. For example, in the face of industries with excess capacity, the most appropriate development and reform path is industrial restructuring. The state should reduce the capital investment in such industries, and put the original capital into potential emerging industries to encourage the development of emerging industries. At the same time, we should strengthen the credit assistance for these potential emerging industries, so as to guide the effective and targeted flow of funds towards the direction of targeted industrial structure transformation.

\section{References}

1. Cimoli, M., Pereira, W., Porcile, G., Scatolin, F., Structure change, technology, and economic growth: Brazil and the CIBS in a comparative perspective[J]. Economic Change and Restructuring, 2011, 44(1-2): 25-47.

2. Aghion P., P. Howitt, D. Mayerfoulkes, The Effect of Financial Development on Convergence: Theory and Evidence[J], The quarterly Journal of Economics, 2005: 173-222

3. Gong Qiang, Zhang Yilin, Lin Yifu. Industrial structure, risk characteristics and optimal financial structure [J]. Economic research. 2014. (4): 4-16. (in Chinese)

4. Yedezhu, Zeng Fanqing. Financial structure suitability and economic growth [j]. Economist.2018 (4) 63-72 (in Chinese)

5. Zheng Wei, Lu Yuanquan. Spatial structure and industrial structure upgrading of China's financial supply [J]. International financial research. 2019 (2): 13-22 (in Chinese)

6. Lin Yifu. New structural economics, viability and new theoretical insights $[\mathrm{J}]$. Journal of Wuhan University (PHILOSOPHY AND SOCIAL SCIENCES EDITION). 2017. (6): 5-15. (in Chinese)

7. Wang Pengbo, Yu Tao, Wang Wangping. Financial development, financial structure and financial growth: an analysis based on Provincial Panel Data [J]. Exploration of economic problems, 2017: (1) 120-127 (in Chinese)

8. Jia Qingxian, Zhu Minglai. Research on the relationship between industrial structure, trade openness and M2 / GDP ratio -- Empirical Test Based on developed economies and emerging market countries $[\mathrm{J}]$, industrial technology economy, 2017, issue 8. (in Chinese)

9. Leng Yanli, Du Sizheng. Financial development, industrial structure and economic growth [J],
Journal of Capital University of economics and trade, 2016, issue 5. (in Chinese)

10. Li Chunsheng, Zhang Liancheng. Research on the interactive relationship between economic growth and industrial structure in China -- An Empirical Analysis Based on VAR model [J], industrial technology economy, 2015, issue 6. (in Chinese)

11. Liu guangbin. Financial development, industrial upgrading and economic growth: An Empirical Study Based on VAR [J], finance and economy, 2013, issue 11. (in Chinese)

12. Wang $\mathrm{Yu}, \mathrm{Li}$ Jian. The relationship between economic growth and industrial structure under the new normal [j], industrial technology economy, 2016, second issue. (in Chinese) 